\title{
Experimental Breeder Reactor I Preservation Plan
}

\author{
Julie B. Braun
}

October 2006

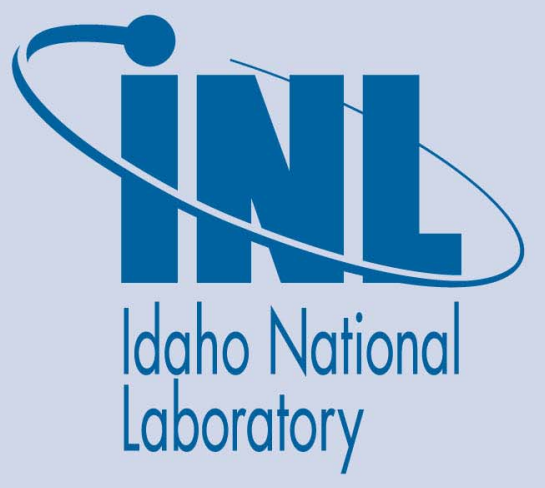

The INL is a U.S. Department of Energy National Laboratory operated by Battelle Energy Alliance 
INL/EXT-06-11909

\title{
Experimental Breeder Reactor I Preservation Plan
}

Julie B. Braun

October 2006

\begin{abstract}
Idaho National Laboratory
Idaho Falls, Idaho 83415
\end{abstract}

http://www.inl.gov

Prepared for the

U.S. Department of Energy

Assistant Secretary for Environmental Management

Under DOE Idaho Operations Office

Contract DE-AC07-05ID14517 


\section{ABSTRACT}

Experimental Breeder Reactor I (EBR I) is a National Historic Landmark located at the Idaho National Laboratory, a Department of Energy laboratory in southeastern Idaho. The facility is significant for its association and contributions to the development of nuclear reactor testing and development. This Plan includes a structural assessment of the interior and exterior of the EBR I Reactor Building from a preservation, rather than an engineering stand point and recommendations for maintenance to ensure its continued protection. 


\section{CONTENTS}

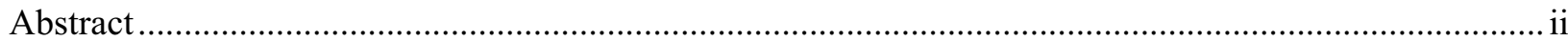

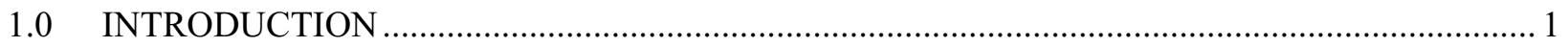

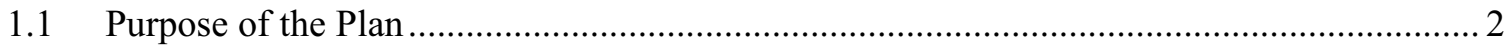

2.0 PHYSICAL AND HISTORICAL SETTING ...................................................................... 3

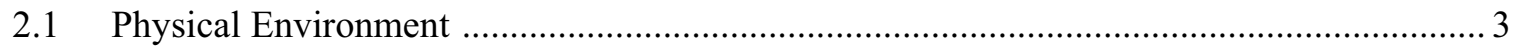

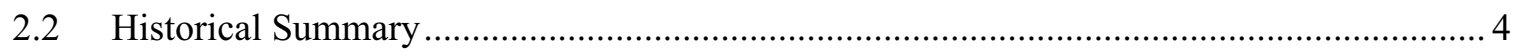

3.0 DESCRIPTION OF EXPERIMENTAL BREEDER REACTOR I REACTOR BUILDING............ 5

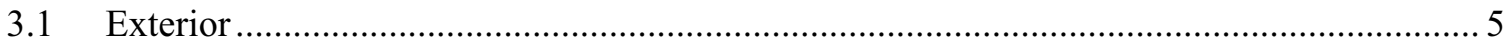

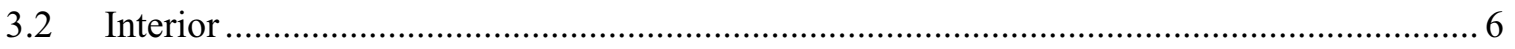

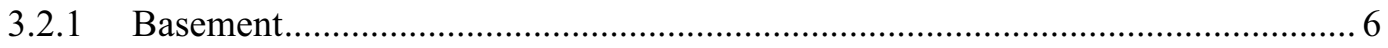

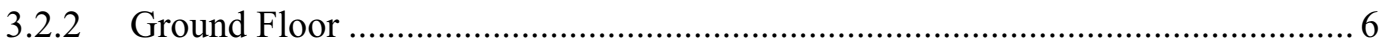

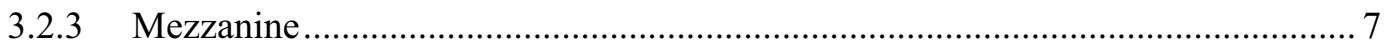

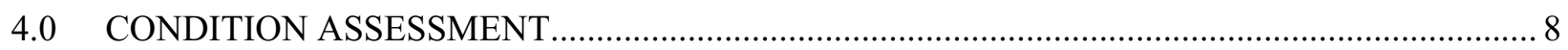

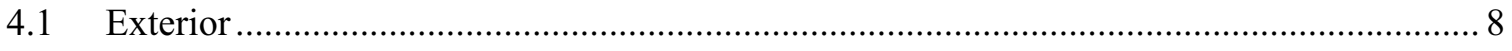

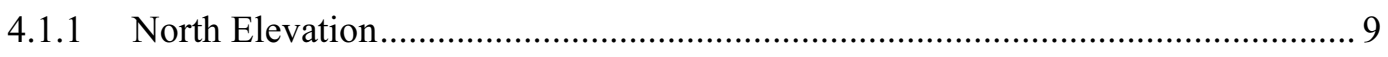

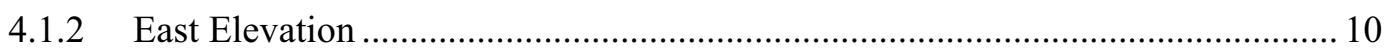

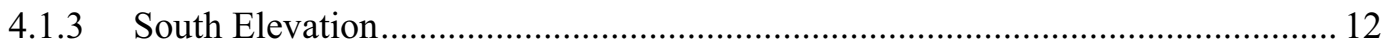

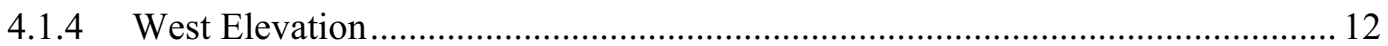

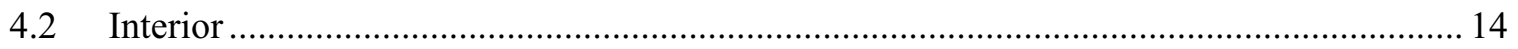

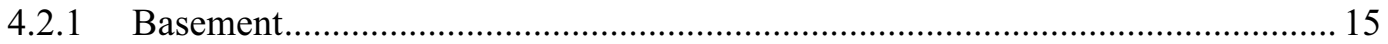

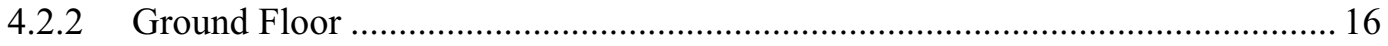

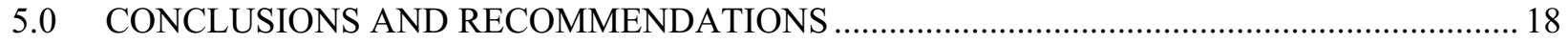

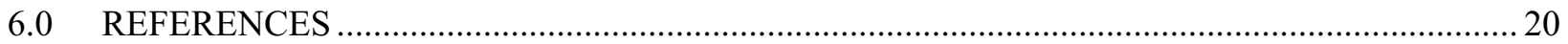




\section{FIGURES}

Figure 1. Experimental Breeder Reactor I Reactor Building, Scoville, Idaho, constructed 1951. ............. 1

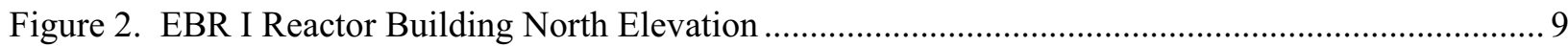

Figure 3. EBR I Reactor Building East Elevations: a) faulty drainage system, b) mismatched brick, c)

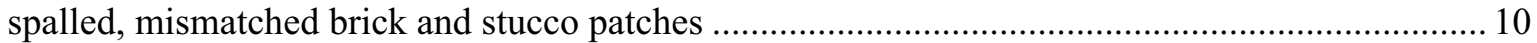

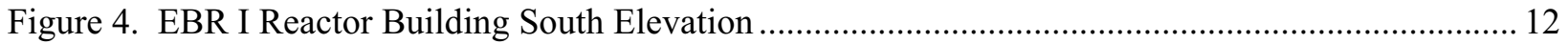

Figure 5. EBR I Reactor Building West Elevation: a) stucco patch removal area, b) efflorescence, c)

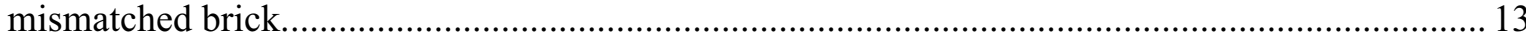

Figure 6. EBR I Reactor Building West Elevations: a) missing and spalled brick on sill, b) reflective

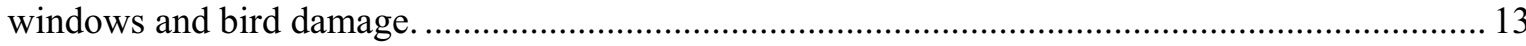

Figure 7. EBR I Reactor Building Basement: a) floor crack, b) stains............................................ 15

Figure 8. EBR I Reactor Building Ground Floor: lack of age-related patina on a) floors, b) equipment,

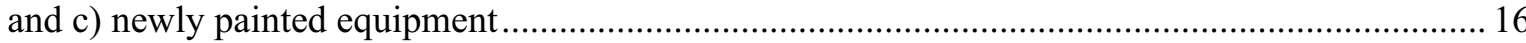

Figure 9. EBR I Reactor Building Ground Floor: stains on floors and walls in a) Service Room, b) near

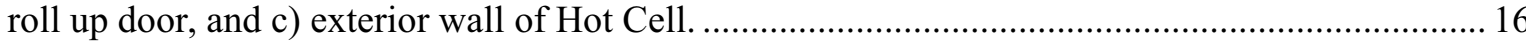

Figure 10. EBR I Reactor Building Ground Floor: brick and mortar damage masked by a) patches and b) painting.

\section{TABLES}

Table 1: EBR I Reactor Building North Elevation Findings ............................................................ 9

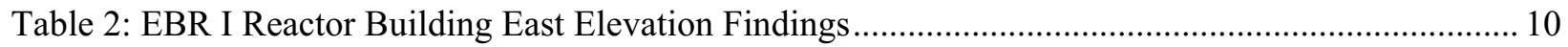

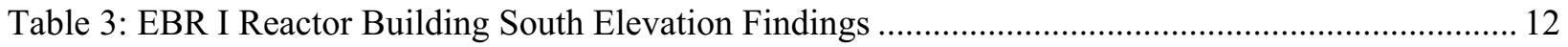

Table 4: EBR I Reactor Building West Elevation Findings ............................................................... 13

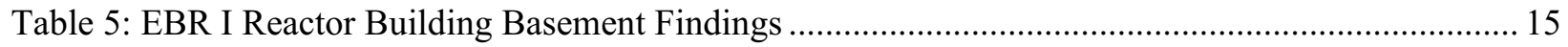

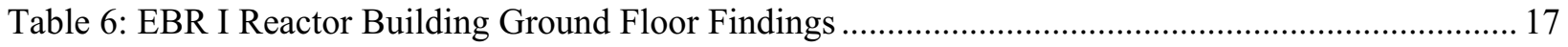




\section{Experimental Breeder Reactor I Preservation Plan 1. INTRODUCTION}

The historical theme of the Experimental Breeder Reactor I (EBR I) Building and Visitors Center is “Nuclear Reactor Testing” (Arrowrock Group 1997). The maintenance goal for this historically significant facility is preservation (Figure1). Although the reactor's most historical event occurred on one day in 1951, the current maintenance objective for the facility is to preserve the historic materials, features, and character of this original mission while also retaining some later elements. Impact assessment, materials repair, and preservation require an understanding of the building, environment and setting, original design and construction, and subsequent changes made through time (Harris 2001, Green 2005, Miller 2005).

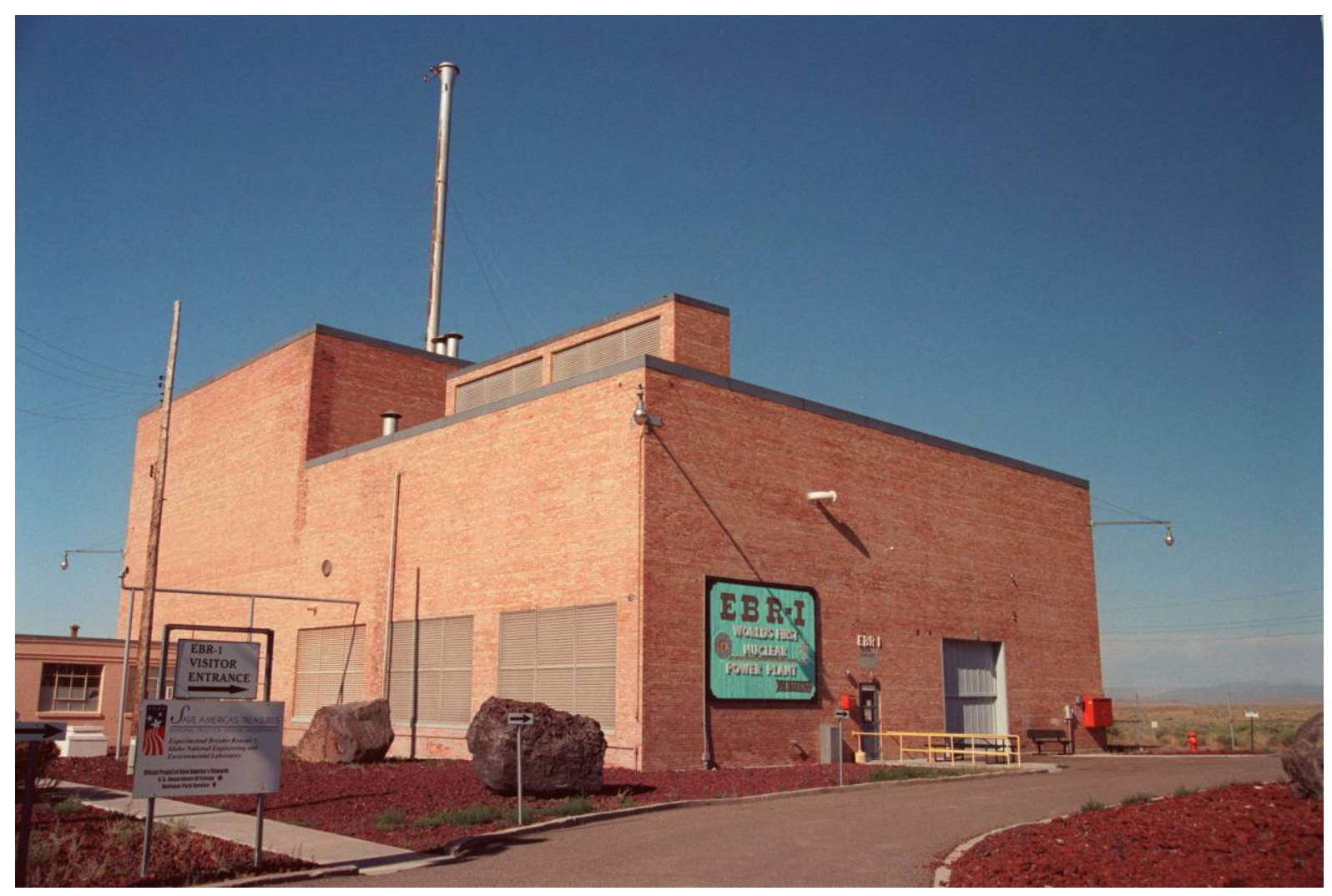

Figure 1. Experimental Breeder Reactor I Reactor Building, Scoville, Idaho, constructed 1951.

The Plan to follow has five sections. Sections 1 and 2 provide background information on EBR I and introduce the stated goal of maintenance for EBR I, which is preservation. Next, the Plan's purpose is presented and the basic elements of a structural assessment are discussed. Section 2 provides a brief 
history of the Landmark and a general description of its physical environment. Section 3 provides a relatively detailed architectural description and layout of the interior and exterior of the EBR I reactor building. This section is intended to provide the basis for the condition assessment as presented in detail in narrative, tables, and photographs in Section 4. Finally, Section 5 provides conclusions from the assessment and makes recommendations for appropriate treatments to be completed or overseen by persons with extensive experience working with historic buildings and fabrics. The recommendations are made to enable the continued preservation, through maintenance, of this important National Historic Landmark.

\subsection{Purpose of the Plan}

The purpose of the EBR I Preservation Plan is to provide a structural assessment of the 54-year old Reactor Building's condition, both internal and external. Additional goals include identification of issues that have impacted, or have the potential to impact it, along with probable causes of the impacts, and lastly to provide options for mitigation and repair. Toward these ends, the Plan contains information gathered from literature review, on-site visits, perusal of engineering and architectural drawings, current and historic photographs and other documents, and discussions with both maintenance and public relations staff with primary responsibility for maintaining the Reactor Building and for promoting it as a heritage tourism property. Historic preservation professionals in the Idaho National Laboratory's Cultural Resource Management (CRM) Office made all of the observations and recommendations contained within the report at the request of the Department of Energy, Idaho Operations Office (DOE-ID). 


\section{PHYSICAL AND HISTORICAL SETTING}

In 1949, the U.S. Atomic Energy Commission (AEC), predecessor agency of the Department of Energy (DOE), established the National Reactor Testing Station, now known as Idaho National Laboratory (INL) in southeastern Idaho. Over the next 30 years, 52 first-of-a-kind and one-of-a-kind reactors were eventually constructed there, nearly all of which made significant contributions to the development of nuclear reactor technology and safety. In 1951, the Bechtel Corporation completed construction on one of the first INL buildings, the EBR I Reactor Building. It was constructed around its central feature, an experimental nuclear reactor.

\subsection{Physical Environment}

INL is located on the arid high desert of the northeastern Snake River Plain in southeastern Idaho (U.S. DOE-ID 2007). Temperature fluctuations are extreme, sometimes reaching 100 degrees Farenheit or more for a short time in the summer and dipping below zero in the winter. Annual precipitation averages only 9 inches, with most falling in the form of winter snow and fall and spring rains. Prevailing diurnal winds blow from southwest to northeast but often reverse direction at night. Topography is subdued and volcanic in origin, with isolated buttes rising as landmarks in the gently rolling basaltic terrain. The Big Lost River passes through the INL area to terminate in a sink area near the foothills of the Lemhi Mountains. Flows in the River today are sporadic due to low precipitation and upstream irrigation demands but evidence is present for higher past flows. Sagebrush and other hardy forbs, cacti, grasses, and shrubs dominate the landscape and during dry years provide abundant fuel for wildfires.

EBR I was built in the southern portion of the INL, approximately two miles south of State Highway 20/26, a mile and a half southeast of the Big Lost River, and approximately five miles northwest of the INL area's largest butte, Big Southern Butte. It sits on a small rise, isolated from most other INL buildings and structures and faces to the northeast.

Prior to 1975, the EBR I complex, both within and outside of a security fence, included the Reactor Building and associated office annex and guardhouse and four additional reactor buildings with associated support structures (U. S. AEC 1969). However, the EBR I area has undergone many changes since its original reactor testing function ended and its new function as a Visitor Center began. The changes include attempts to repair and/or replace materials and systems as well as the removal of all buildings in the area except the EBR I Reactor Building, annex, and guardhouse. Several changes have also been made since 1975 to expand the visitors' experience including development of interpretive exhibits and the introduction of non-nuclear artifacts from across the INL area, and (INEL 1989). 


\subsection{Historical Summary}

On December 20, 1951, the EBR I reactor produced the world's first usable amounts of electricity from a nuclear reactor. Over the next thirteen years, the EBR I reactor went on to achieve many more world firsts and proved its primary mission, that a reactor could produce more fuel than it consumed. The reactor core was changed out four times over the next decade. The final core experienced a partial meltdown that resulted in radiological contamination to some parts of the reactor vessel. In addition, some piping and other building components retained residual radioactive waste from the meltdown and regular reactor testing activities.

The reactor was deactivated in 1963 and, in 1966, President Lyndon B. Johnson designated the Reactor Building a National Historic Landmark for its many achievements in reactor development and design. Following decontamination, in 1975 the Reactor Building and associated Office Annex were opened as a public Visitor Center (Smith et al. 1949:22-23, Stacy 2000:259). The facility remains open to the public today. 


\section{DESCRIPTION OF EXPERIMENTAL BREEDER REACTOR I REACTOR BUILDING}

The EBR I Reactor Building is constructed of concrete, steel, and brick and is the only all brick reactor building constructed on the INL. The Building is a functional, multi-level industrial steel-frame structure consisting of three sections: a central 4-story high-bay, a 2-story low bay to the north of the high bay, and a $1 \frac{1}{2}$ story low bay to the south of the high bay that has a small utility room adjacent to its west wall. The Building faces northeast and is approximately 122 feet long by 77 feet wide. The height of the Building above ground is approximately 50 feet and underground levels extend 30 feet below the surface. Three finished levels are located inside the building, including a partial basement, main ground floor, and mezzanine.

The Building has a concrete foundation and a flat roof comprised of a concrete roof deck with 3ply built up composite asphalt surface. Parapets extend approximately 3 -feet above the roofline. The original concrete coping is now covered with metal. A ventilation penthouse protrudes above the northeast side of the roof and also has a flat roof of composite asphalt with a metal coping.

The setting associated with the Reactor Building is also a historic character defining feature (Harris 2001: 438-441). Two single bulb metal yard lights extend from the corner of the walls on the building's north side and utility lights hang above each overhead door. A lawn once graced the area immediately adjacent to the reactor building, but has been replaced with local red cinder interspersed with new concrete sidewalks designed to allow wheelchair access.

\subsection{Exterior}

As-built engineering drawings available from the INL Records Storage Center (EB 51-59 and 75, Box 166075, Rolls 2-3) show that all exterior wall elevations are brick with five stringer courses to every header course, north and south wall elevations are triple wythe and east and west walls are double wythe. The brick, including that used for the parapets, is multi-colored and mortar comprises approximately $30 \%$ of the wall. The walls are reinforced at each of the building corners with $1 / 4$ " steel rods. Engineering drawings indicate that the main sections of the building had a drained cavity system with an interior downspout. The system is not visible from the interior and, if it exists, is likely concealed between the interior and exterior walls. There is evidence of drain holes in the walls, as well as exterior drain pipes.

The north elevation features a centered gray steel entry door with a single pane fixed window. Adjacent to the entryway is a gray steel overhead garage door that leads directly into the high bay. Two 
other pedestrian and overhead doors exist, one that leads into the southern low bay and the other into the west side of the high bay.

The only fenestration occurs on the west elevation. There are two ribbons of three casement steelframed windows that extend about 20 feet above the ground and double-hung steel-framed windows in each second floor rest room. There is also a single window above the west interior stair landing and three louvered metal vents on the reactor building and ventilation penthouse's east elevations.

\subsection{Interior}

The interior of the EBR I Reactor Building reflects the building's historic use and has three levels: a partial basement, ground floor, and mezzanine.

\subsubsection{Basement}

The basement has two drain tanks, an access space, and eleven rooms (two reflector repair rooms, a conveyor room, three pump rooms, a wash room, an exhauster room, a receiver room, a cold pump room, and a handling room). Several of the partial basement's rooms are not accessible due to some residual contamination. The floor is concrete and the walls are concrete with reinforcing steel. There are no windows and artificial light is provided by several single bulb drop fixtures.

\subsubsection{Ground Floor}

The ground floor has eight rooms (turbine room, service room, load dissipation room, steam generator room, reactor room, convection room, vault room, and fuel handling cave or hot cell). Adjacent to the convection room is the concrete reactor containment vessel. The rod farm and top of the basement wash room are located across from it. The ground floor has walls of exposed brick, concrete block, and concrete reinforced with steel. Exposed piping and ductwork run between the rooms and some equipment is newly painted in bright colors. The concrete floor is waxed to a high sheen. Unfortunately, new paint and extensive cleaning and waxing removes the patina of age. Paint may also actually hide structural problems (Miller 2005).

Narrow concrete stairs with black and yellow safety tape on the risers and yellow safety netting strapped to the rails are located in four areas of the ground floor. Two go upstairs and are located in the turbine room's northwest corner and south of the entrance vestibule. The other two go downstairs and are adjacent to the south wall of the service room and in the reactor room's southeast corner. 
The Building does not have a humidifier or furnace. Heat is provided by electric baseboard units. White ceiling fans hang from the steel girders and natural light enters the floor from one window on the first landing of stairs in the northwest corner and from the single window on the entry door. However, several green metal single-bulb fixtures and newer silver metal fixtures provide artificial light.

\subsubsection{Mezzanine}

The Mezzanine has a total of eight rooms (women's and men's restrooms, a closet, office/storage room, turbine/gear box/generator space, reactor control room, and gravity tank room). The top of the Reactor is located adjacent to the gravity tank room and has a walkway around three sides. Outside walls are of brick and interior walls are of concrete block and concrete reinforced with steel with the exception of the northern exterior of the control room wall. It is a combination of exposed brick, concrete and concrete block. All floors are concrete; however, the floor in the office/storage room has been covered with blue indoor/outdoor carpet and the control room has 8 " x 8 " mottled brown asbestos tile. Natural light comes into the office/storage room from two sets of steel-framed casement-type west-facing windows. Each restroom also has one west-facing window. Artificial light is provided by the same green metal and newer silver metal fixtures that provide light to the ground floor. 


\section{CONDITION ASSESSMENT}

The following discussion is organized according to exterior elevations (north, east, south, west) and interior level (basement, ground floor).

\subsection{Exterior}

From a distance the EBR I Reactor Building's exterior appears to be in good condition. However, closer inspection reveals several problems, particularly on the windward west side. Spalling brick, deteriorating mortar, and efflorescence appear to be longtime issues. The brick was sandblasted in 1981 increasing its porosity and susceptibility to water penetration. Attempts at repair include the use of nonmatching brick and mortar and stucco patches applied directly to the brick surface.

Drainage problems are also chronic at the Reactor Building, possibly exacerbated by a flat roof and inappropriate maintenance (Harris 2001:547, 588-589, Fielden 2003:70-71). Drain holes in the masonry walls have been plugged with concrete and exterior drain pipes installed that, in some cases, do not adequately direct water away from the foundation or walls. A visit to the Building during and immediately after a rainstorm showed that water is hitting the ground and splashing back on the concrete foundation. Rainwater was also observed running down the masonry walls on the Building's west elevation and in the southwest corner. A variety of negative impacts are present as a result: wet masonry; spalling concrete, mortar deterioration, and loss of rendering. These forces are problematic because they leave soft brick face exposed, which will allow further moisture penetration and materials deterioration (Harris 2001:92-93, Weaver 1997:145-146, Green 2005, Miller 2005).

From the ground, diagonal cracks were observed in the northeast and southeast parapets, resulting in negative impacts. Bird droppings were seen on the west window sills and small peck marks were noted in the window glass causing small window cracks. The negative effects of birds and other natural agents are widely known (Fieldlen 2003:27, 62, 115, Harris 2001:589, Weaver 1997:117-119, Green 2005, Miller 2005).

Discussion of deterioration forces related to brick and mortar, appearance, and possible treatments is found in Fielden (2003:66-70, 195-198, 263-6), Weaver (1997:102-105), Harris (2001:26), Green (2005) and Miller (2005). Historical architect and structural engineer Mel Green advises (2005), "Don't put anything on a building out of a can," and "always wait to see if new products work." In general, all sources agree that non-public areas are not as important for appearances as public areas (cf. Fielden 2003:66, 195). Consensus is also reached on the importance of utilizing Conservators, Structural 
Engineers, and Master Craftsmen with professional experience in the preservation and rehabilitation of historic buildings. Cleaning and maintenance staff must also be aware of special requirements for historic buildings and should track and report their observations and decisions.

\subsubsection{North Elevation}

Findings for the north elevation of the EBR I Reactor Building are summarized below (Figure 2, Table 1). The Building warrants continued monitoring so that any future flooding issues, which have adversely affected the structure in the past, are corrected quickly. Assessment and future repair under the direction of qualified professionals are also recommended.

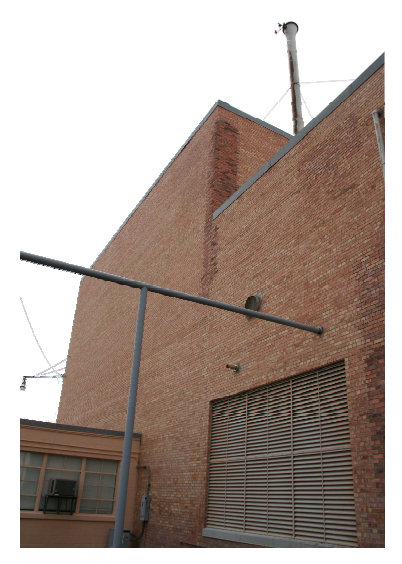

Figure 2. EBR I Reactor Building North Elevation.

Table 1. EBR I Reactor Building North Elevation findings.

\begin{tabular}{|c|c|c|c|c|}
\hline Issue & Probable Cause & $\begin{array}{l}\text { Testing and } \\
\text { Investigation }\end{array}$ & $\begin{array}{l}\text { Impact on the } \\
\text { Structure }\end{array}$ & Mitigation and Repair \\
\hline $\begin{array}{l}\text { Diagonal } \\
\text { cracks in the } \\
\text { parapet wall. } \\
\text { Likely also } \\
\text { present at } \\
\text { other parapet } \\
\text { corners } \\
\text { (Figure 2) }\end{array}$ & $\begin{array}{l}\text { Unequal settlement } \\
\text { leading to uneven loads; } \\
\text { insufficient bond; } \\
\text { Thermal movement and } \\
\text { moisture expansion, } \\
\text { freeze/thaw cycles. 1/4" } \\
\text { steel reinforcement rods } \\
\text { and no expansion or } \\
\text { contraction joints in the } \\
\text { parapet walls. }\end{array}$ & $\begin{array}{l}1980 \text { project } \\
\text { drawings; } \\
\text { Visual } \\
\text { inspection }\end{array}$ & $\begin{array}{l}\text { Deterioration of } \\
\text { parapet corners } \\
\text { leading to } \\
\text { possible failure of } \\
\text { parapet walls. }\end{array}$ & $\begin{array}{l}\text { Employ Structural Engineer } \\
\text { with professional experience } \\
\text { in historic structures to: } \\
\text { analyze stress, strain, and } \\
\text { torsion related to dead and } \\
\text { live loads and the } \\
\text { environment; and to } \\
\text { recommend treatment options. } \\
\text { Contract with Conservator } \\
\text { with professional experience } \\
\text { in historic masonry, to work } \\
\text { with Structural Engineer and } \\
\text { Landlord and to conduct or } \\
\text { oversee repair. }\end{array}$ \\
\hline
\end{tabular}


Table 1 continued.

\begin{tabular}{|l|l|l|l|l|}
\hline \multicolumn{1}{|c|}{ Issue } & \multicolumn{1}{|c|}{ Probable Cause } & $\begin{array}{l}\text { Testing and } \\
\text { Investigation }\end{array}$ & $\begin{array}{l}\text { Impact on the } \\
\text { Structure }\end{array}$ & Mitigation and Repair \\
\hline \hline $\begin{array}{l}\text { Mismatched } \\
\text { brick (Figure }\end{array}$ & $\begin{array}{l}\text { Initial damage caused by } \\
\text { broken waterline and } \\
\text { resulting flood. Problem } \\
\text { fixed; 1980 brick repair } \\
\text { and replacement } \\
\text { overseen and completed } \\
\text { by persons with no } \\
\text { historic building or } \\
\text { materials experience. }\end{array}$ & $\begin{array}{l}\text { Project } \\
\text { drawings; } \\
\text { conduct brick } \\
\text { dye test on } \\
\text { small section of } \\
\text { brick on } \\
\text { west/south } \\
\text { "nonpublic" } \\
\text { side of building }\end{array}$ & $\begin{array}{l}\text { Detracts from } \\
\text { historic } \\
\text { appearance }\end{array}$ & $\begin{array}{l}\text { Contract with Conservator } \\
\text { with professional experience } \\
\text { in historic masonry to oversee } \\
\text { or conduct masonry work } \\
\text { including repointing } \\
\text { replacement with materials } \\
\text { that match original in } \\
\text { composition, color, and size. }\end{array}$ \\
\hline
\end{tabular}

\subsubsection{East Elevation}

Findings for the east elevation of the EBR I Reactor Building are summarized below (Figure 3, Table 2). A faulty drainage system has adversely affected the building on this side and repairs are recommended to halt further deterioration.

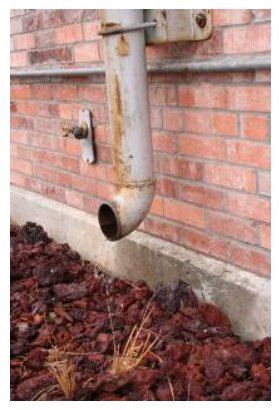

a

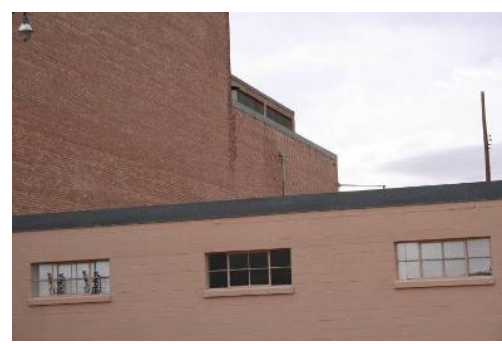

b

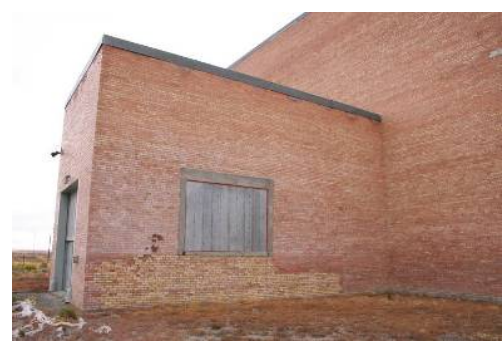

c

Figure 3. EBR I Reactor Building East Elevations: a) faulty drainage system, b) mismatched brick, c) spalled, mismatched brick and stucco patches.

Table 2. EBR I Reactor Building East Elevation findings.

\begin{tabular}{|c|c|c|c|c|}
\hline Issue & Probable Cause & $\begin{array}{l}\text { Testing and } \\
\text { Investigation }\end{array}$ & $\begin{array}{l}\text { Impact on the } \\
\text { Structure }\end{array}$ & Mitigation and Repair \\
\hline $\begin{array}{l}\text { Wet } \\
\text { masonry; } \\
\text { Spalling } \\
\text { Concrete, } \\
\text { (Figure 3a) }\end{array}$ & $\begin{array}{l}\text { Faulty drainage; exterior } \\
\text { drainpipe does not carry } \\
\text { water away from } \\
\text { building, causes } \\
\text { splashing from rock onto } \\
\text { concrete; saturates soil }\end{array}$ & $\begin{array}{l}1980 \text { project } \\
\text { drawings; } \\
\text { visual } \\
\text { inspection and } \\
\text { damp concrete }\end{array}$ & $\begin{array}{l}\text { Weakened } \\
\text { foundation; create } \\
\text { pathway for } \\
\text { additional water }\end{array}$ & $\begin{array}{l}\text { Contract with Structural } \\
\text { Engineer to work with } \\
\text { Mechanical Systems Engineer } \\
\text { to determine if original interior } \\
\text { cavity drain system is } \\
\text { operational. Determine }\end{array}$ \\
\hline
\end{tabular}


Table 2 continued.

\begin{tabular}{|c|c|c|c|c|}
\hline Issue & Probable Cause & $\begin{array}{l}\text { Testing and } \\
\text { Investigation }\end{array}$ & $\begin{array}{l}\text { Impact on the } \\
\text { Structure }\end{array}$ & Mitigation and Repair \\
\hline & $\begin{array}{l}\text { causing capillary action } \\
\text { (rising damp). }\end{array}$ & & & $\begin{array}{l}\text { functionality of external } \\
\text { system and recommend } \\
\text { treatment. } \\
\text { Contract with Master } \\
\text { Craftsman to oversee } \\
\text { repair/replacement of drainage } \\
\text { system and components. }\end{array}$ \\
\hline $\begin{array}{l}\text { Mismatched } \\
\text { brick on } \\
\text { "public" } \\
\text { reactor } \\
\text { building } \\
\text { wall (Figure } \\
\text { 3b) }\end{array}$ & $\begin{array}{l}\text { Clogged drainbody or } \\
\text { downspout at this corner } \\
\text { of the roof replaced with } \\
\text { external drain pipe. } \\
\text { Problem fixed. }\end{array}$ & $\begin{array}{l}1980 \text { Project } \\
\text { drawings; } \\
\text { conduct brick } \\
\text { dye test on } \\
\text { small section of } \\
\text { brick on } \\
\text { west/south } \\
\text { "nonpublic" } \\
\text { side of building }\end{array}$ & $\begin{array}{l}\text { Detracts from } \\
\text { historic } \\
\text { appearance }\end{array}$ & $\begin{array}{l}\text { Contract with Conservator } \\
\text { with professional experience } \\
\text { in historic masonry to oversee } \\
\text { or conduct masonry work by } \\
\text { Master Craftsmen including } \\
\text { repointing replacement, with } \\
\text { materials that match original in } \\
\text { composition, color, and size. }\end{array}$ \\
\hline $\begin{array}{l}\text { Mismatched } \\
\text { brick on } \\
\text { "nonpublic" } \\
\text { vault room } \\
\text { wall (Figure } \\
\text { 3c) }\end{array}$ & $\begin{array}{l}2003 \text { brick repair and } \\
\text { replacement overseen } \\
\text { and completed by } \\
\text { persons with no historic } \\
\text { building or materials } \\
\text { experience. }\end{array}$ & $\begin{array}{l}2003 \text { Project } \\
\text { drawings; } \\
\text { conduct brick } \\
\text { dye test on } \\
\text { small section of } \\
\text { brick on this } \\
\text { wall }\end{array}$ & $\begin{array}{l}\text { Detracts from } \\
\text { historic } \\
\text { appearance }\end{array}$ & $\begin{array}{l}\text { Contract with Conservator } \\
\text { with extensive historic } \\
\text { masonry experience to oversee } \\
\text { or conduct masonry work } \\
\text { including repointing } \\
\text { replacement, with materials } \\
\text { that match original in } \\
\text { composition, color, profile, } \\
\text { texture, and size. }\end{array}$ \\
\hline $\begin{array}{l}\text { Stucco } \\
\text { patches } \\
\text { pulling away } \\
\text { and } \\
\text { removing } \\
\text { brick } \\
\text { rendering; } \\
\text { spalled brick } \\
\text { on } \\
\text { "nonpublic" } \\
\text { vault room } \\
\text { wall (Figure } \\
\text { 3c) }\end{array}$ & $\begin{array}{l}\text { Moisture penetrating } \\
\text { brick from opening lap } \\
\text { joint in the coping. } \\
\text { Lawn watering on lee } \\
\text { side of building caused } \\
\text { brick deterioration and } \\
\text { persons with no } \\
\text { experience with historic } \\
\text { buildings or materials } \\
\text { oversaw or completed } \\
1980 \text { repair project. }\end{array}$ & $\begin{array}{l}1980 \text { project } \\
\text { drawings; } \\
\text { interview with } \\
\text { EBR I retiree; } \\
\text { site visit during } \\
\text { rain storm, } \\
\text { visual } \\
\text { inspection }\end{array}$ & $\begin{array}{l}\text { Spalled brick, } \\
\text { mortar } \\
\text { deterioration. } \\
\text { Loss of rendering } \\
\text { will leave soft } \\
\text { brick face } \\
\text { exposed; missing } \\
\text { brick will allow } \\
\text { further moisture } \\
\text { penetration and } \\
\text { materials } \\
\text { deterioration. }\end{array}$ & $\begin{array}{l}\text { Contract with Structural } \\
\text { Engineer to determine extent } \\
\text { of coping issue. Under } \\
\text { supervision of Structural } \\
\text { Engineer with professional } \\
\text { historic masonry experience, } \\
\text { have Master Craftsman } \\
\text { remove lower side metal } \\
\text { coping and reinstall after } \\
\text { masonry is repaired. } \\
\text { Contract with Conservator } \\
\text { with extensive historic } \\
\text { masonry experience to oversee } \\
\text { or conduct masonry work by } \\
\text { Master Craftsmen including } \\
\text { repointing replacement, with } \\
\text { materials that match original in } \\
\text { composition, color, and size. } \\
\text { Lawn has been replaced by red } \\
\text { cinders and watering is no } \\
\text { longer a problem. }\end{array}$ \\
\hline
\end{tabular}




\subsubsection{South Elevation}

Findings for the south elevation of the EBR I Reactor Building are summarized below (Figure 4, Table 3).

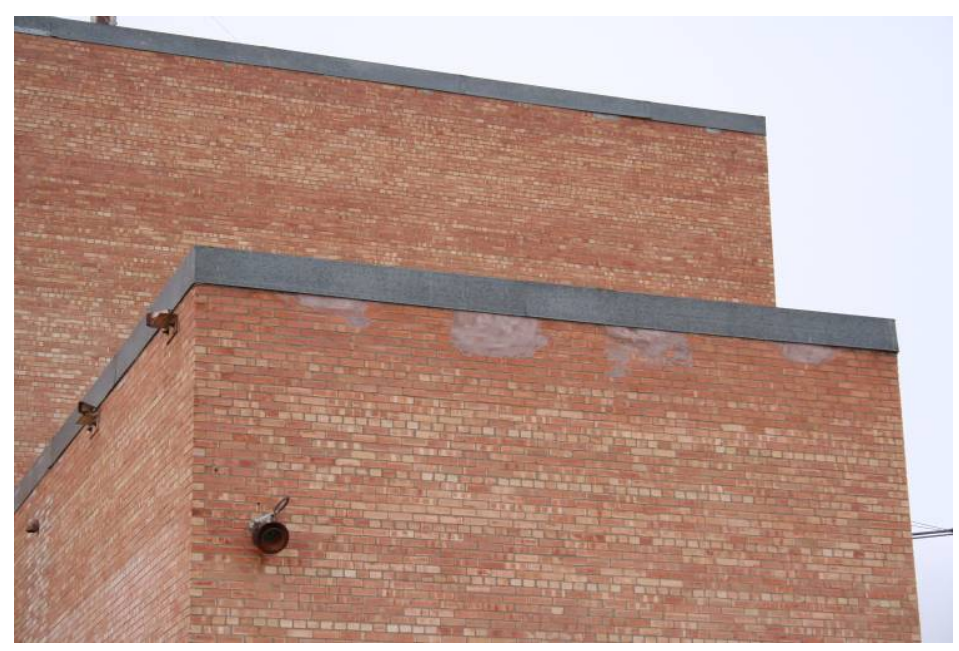

Figure 4. EBR I Reactor Building South Elevation.

Table 3. EBR I Reactor Building South Elevation findings.

\begin{tabular}{|l|l|l|l|l|}
\hline \multicolumn{1}{|c|}{ Issue } & Probable Cause & \multicolumn{1}{|c|}{$\begin{array}{c}\text { Testing and } \\
\text { Investigation }\end{array}$} & $\begin{array}{l}\text { Impact on the } \\
\text { Structure }\end{array}$ & Mitigation and Repair \\
\hline \hline $\begin{array}{l}\text { Stucco patches } \\
\text { cover spalled } \\
\text { brick on } \\
\text { "nonpublic" } \\
\text { reactor building } \\
\text { walls (Figure 4) }\end{array}$ & $\begin{array}{l}\text { Moisture } \\
\text { penetrating the } \\
\text { brick from an } \\
\text { opening in the lap } \\
\text { joint in the } \\
\text { coping. }\end{array}$ & $\begin{array}{l}1980 \text { project } \\
\text { drawings; Site visit } \\
\text { during rain storm, } \\
\text { visual inspection; } \\
\text { stucco patches in } \\
\text { good condition }\end{array}$ & $\begin{array}{l}\text { Detracts from } \\
\text { historic } \\
\text { appearance }\end{array}$ & $\begin{array}{l}\text { Monitor joints in metal coping } \\
\text { and stucco for cracking; } \\
\text { Consult Structural or Systems } \\
\text { Engineer with experience } \\
\text { regarding historic drainage } \\
\text { systems to determine if } \\
\text { drainage system is plugged } \\
\text { and where. }\end{array}$ \\
\hline
\end{tabular}

\subsubsection{West Elevation}

Findings for the west elevation of the EBR I reactor building are summarized below (Figures 5 and 6, Table 4). 


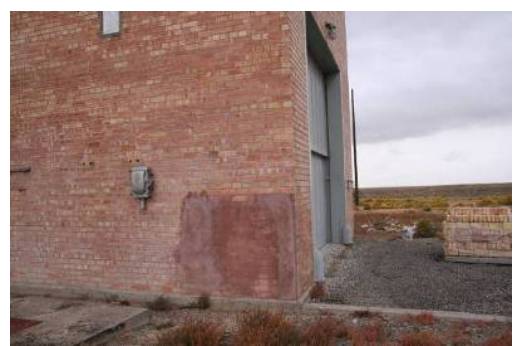

a

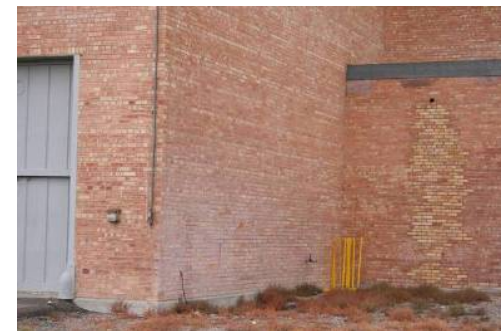

b

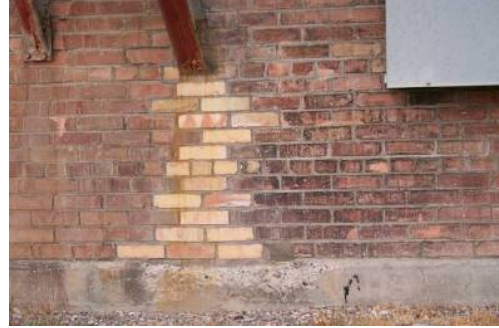

c

Figure 5. EBR I Reactor Building West Elevation: a) stucco patch removal area, b) efflorescence, c) mismatched brick.

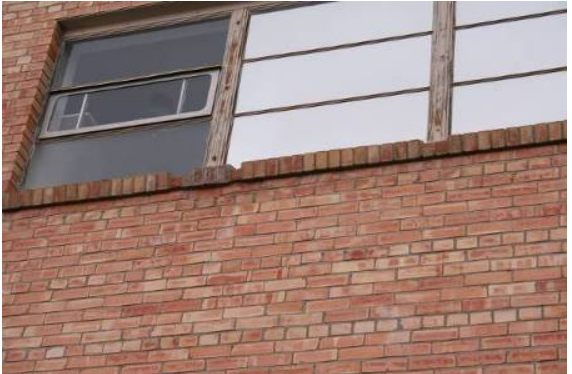

a

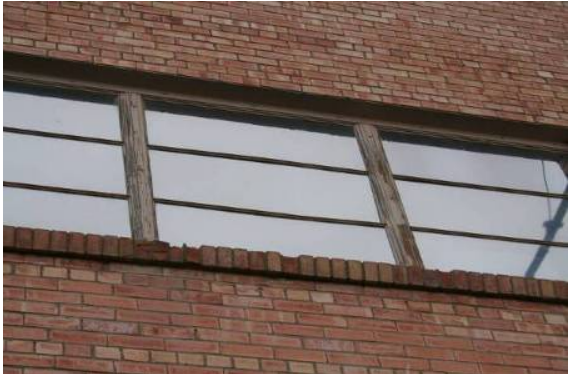

b

Figure 6. EBR I Reactor Building West Elevation: a) missing and spalled brick on sill, b) reflective windows and bird damage.

Table 4. EBR I Reactor Building West Elevation findings.

\begin{tabular}{|c|c|c|c|c|}
\hline Issue & Probable Cause & $\begin{array}{c}\text { Testing and } \\
\text { Investigation }\end{array}$ & $\begin{array}{c}\text { Impact on the } \\
\text { Structure }\end{array}$ & Mitigation and Repair \\
\hline $\begin{array}{l}\text { Removal of } \\
\text { stucco patch left } \\
\text { stains and soft } \\
\text { brick beneath. } \\
\text { (Figure 5a). Salt } \\
\text { leaching from } \\
\text { brick Reactor } \\
\text { Building wall } \\
\text { (efflorescence) } \\
\text { (Figure 5b); Wet } \\
\text { masonry. } \\
\text { Mismatched } \\
\text { brick on } \\
\text { "nonpublic" } \\
\text { vault room wall } \\
\text { (Figure 5c) }\end{array}$ & $\begin{array}{l}\text { Wall located on } \\
\text { windward side of } \\
\text { Exterior pipe is } \\
\text { missing and water } \\
\text { is draining directly } \\
\text { onto wall. Persons } \\
\text { with no experience } \\
\text { with historic } \\
\text { buildings or } \\
\text { materials oversaw } \\
\text { or completed } 2003 \\
\text { masonry repair } \\
\text { project. }\end{array}$ & $\begin{array}{l}2003 \text { Project } \\
\text { drawings; conduct } \\
\text { brick dye test on } \\
\text { small section of } \\
\text { brick on this wall }\end{array}$ & $\begin{array}{l}\text { Spalled brick, } \\
\text { mortar } \\
\text { deterioration; } \\
\text { missing brick will } \\
\text { allow further } \\
\text { moisture } \\
\text { penetration and } \\
\text { materials } \\
\text { deterioration. }\end{array}$ & $\begin{array}{l}\text { Contract with Structural } \\
\text { Engineer to work with } \\
\text { Mechanical Systems } \\
\text { Engineer to determine if } \\
\text { original interior cavity drain } \\
\text { system is operational. } \\
\text { Determine functionality of } \\
\text { external system and } \\
\text { recommend treatment. } \\
\text { Contract with Master } \\
\text { Craftsman to oversee } \\
\text { repair/replacement of } \\
\text { drainage system and } \\
\text { components. } \\
\text { Contract with Conservator } \\
\text { with professional historic } \\
\text { masonry experience to } \\
\text { oversee or conduct masonry } \\
\text { work by Master Craftsmen }\end{array}$ \\
\hline
\end{tabular}


Table 4 continued.

\begin{tabular}{|l|l|l|l|l|}
\hline \multicolumn{1}{|c|}{ Issue } & Probable Cause & \multicolumn{1}{c|}{$\begin{array}{c}\text { Testing and } \\
\text { Investigation }\end{array}$} & $\begin{array}{l}\text { Impact on the } \\
\text { Structure }\end{array}$ & \multicolumn{1}{|c|}{ Mitigation and Repair } \\
\hline \hline $\begin{array}{l}\text { Missing and } \\
\text { spalled brick on } \\
\text { rowlock brick sill } \\
\text { (Figure 6a, b) }\end{array}$ & $\begin{array}{l}\text { Deteriorating } \\
\text { mortar joints on } \\
\text { brick sill; moisture } \\
\text { and freeze/thaw; }\end{array}$ & Visual Inspection & $\begin{array}{l}\text { Rowlock brick sill } \\
\text { is deteriorating } \\
\text { and will worsen if } \\
\text { no intervention. }\end{array}$ & $\begin{array}{l}\text { including repointing } \\
\text { replacement, with materials } \\
\text { that match original in } \\
\text { composition, color, and size. }\end{array}$ \\
$\begin{array}{l}\text { Engineer to determine if there } \\
\text { may be other causes (i.e., } \\
\text { steel reinforcement at corner } \\
\text { of window) and Conservator } \\
\text { with professional historic } \\
\text { masonry experience to } \\
\text { oversee or conduct masonry } \\
\text { work by Master Craftsmen } \\
\text { including repointing } \\
\text { replacement, with materials } \\
\text { that match original in } \\
\text { composition, color, and size. }\end{array}$ \\
\hline $\begin{array}{l}\text { Peck marks and } \\
\text { cracks in } \\
\text { windows; bird } \\
\text { droppings on } \\
\text { window sill and } \\
\text { down masonry } \\
\text { wall (Figure 6b) }\end{array}$ & $\begin{array}{l}\text { Birds attracted to } \\
\text { reflective film on } \\
\text { windows }\end{array}$ & Visual Inspection & $\begin{array}{l}\text { Potential for } \\
\text { broken windows } \\
\text { and entry of birds } \\
\text { into building } \\
\text { interior. } \\
\text { Droppings may } \\
\text { cause materials to } \\
\text { decay. }\end{array}$ & $\begin{array}{l}\text { Remove reflective film, } \\
\text { install one-way interior } \\
\text { shades to allow visitors to } \\
\text { look out while reducing glare } \\
\text { and heat. Apply black nylon } \\
\text { thread about 1" above sills } \\
\text { and other landing edges to } \\
\text { discourage perching birds. }\end{array}$ \\
\hline
\end{tabular}

\subsection{Interior}

Water penetration, a faulty drainage system, and over-zealous maintenance have adversely affected the interior fabric of the EBR I reactor building. Extensive water stains and spalling concrete occur along the west wall in the basement and a long but narrow crack appears at the bottom of one set of basement steps. The entire area smells musty but appears to be clean.

The ground floor generator room and area near the hot cell also shows signs of water penetration. The brick is spalling and the mortar is deteriorating on the west wall from the floor to approximately 8 " up. Extensive water stains also occur in these locations and the areas smell musty. However, there is no evidence of mold here or in the basement or of recent water penetration.

The floor in front of the north garage door has a large water stain. A retired employee stated that years ago, a water line broke in this area and water flooded that area of the floor. He indicated that the 
stain was a remnant of that event. Further discussions with the building's landlord revealed that no further flooding had occurred in that area (Miley and Summers 2005)

Materials on the mezzanine appear to be in very good condition with no issues noted. However, the lack of window coverings in the office/storage room make the room very hot and uncomfortable, particularly in late summer afternoons, and the peck marks noted on the exterior are also visible from the interior of this room.

\subsubsection{Basement}

Water has impacted the basement of the EBR I reactor building as summarized in the following photographs (Figure 7) and Table (Table 5).

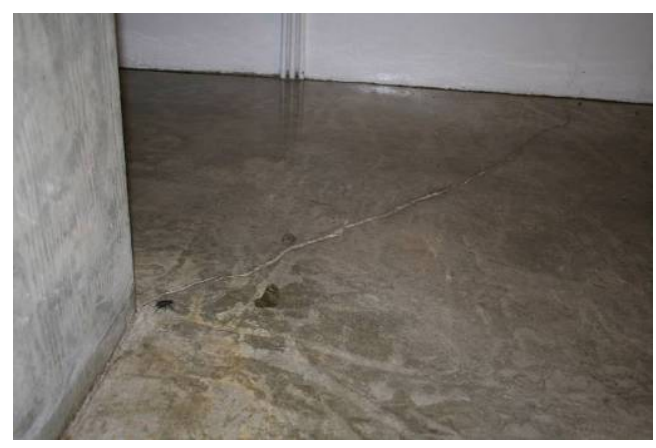

a

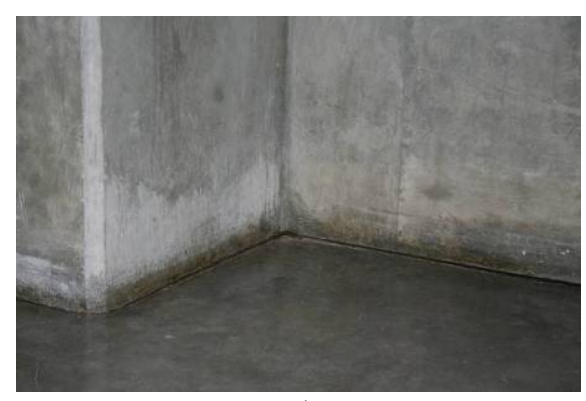

b

Figure 7. EBR I Reactor Building Basement: a) floor crack, b) stains.

Table 5. EBR I Reactor Building Basement findings.

\begin{tabular}{|l|l|l|l|l|}
\hline \multicolumn{1}{|c|}{ Issue } & \multicolumn{1}{|c|}{$\begin{array}{c}\text { Probable } \\
\text { Cause }\end{array}$} & $\begin{array}{c}\text { Testing and } \\
\text { Investigation }\end{array}$ & $\begin{array}{l}\text { Impact on the } \\
\text { Structure }\end{array}$ & Mitigation and Repair \\
\hline \hline $\begin{array}{l}\text { Crack in } \\
\text { concrete } \\
\text { floor of } \\
\text { basement } \\
\text { (Figure 7a) }\end{array}$ & $\begin{array}{l}\text { Compression } \\
\text { soon after } \\
\text { construction or } \\
\text { when adjacent } \\
\text { building } \\
\text { removed }\end{array}$ & $\begin{array}{l}\text { Crack gauge to } \\
\text { evaluate } \\
\text { movement }\end{array}$ & $\begin{array}{l}\text { Crack may spread } \\
\text { causing pathway } \\
\text { for moisture } \\
\text { penetration }\end{array}$ & Continued monitoring \\
\hline $\begin{array}{l}\text { Stains on } \\
\text { floor and } \\
\text { walls of } \\
\text { basement } \\
\text { (Figure 7b) }\end{array}$ & $\begin{array}{l}\text { Water seepage } \\
\text { on Westside of } \\
\text { Reactor Building }\end{array}$ & $\begin{array}{l}\text { Surveillance } \\
\text { after rain and } \\
\text { snow melt }\end{array}$ & $\begin{array}{l}\text { Stains and } \\
\text { deterioration of } \\
\text { concrete }\end{array}$ & $\begin{array}{l}\text { Some drainage problems } \\
\text { have been fixed; monitor to } \\
\text { see if moisture is present } \\
\text { after rains and snows; if } \\
\text { water is present, track on } \\
\text { exterior of building and } \\
\text { identify cause (i.e., coping } \\
\text { gaps) }\end{array}$ \\
\hline
\end{tabular}




\subsubsection{Ground Floor}

Walls and floors on the ground floor of the EBR I reactor building have been impacted by water and maintenance activities not sympathetic to the historic architecture. Findings are summarized in the photographs (Figures 8, 9, and 10) and Table (Table 6) to follow.

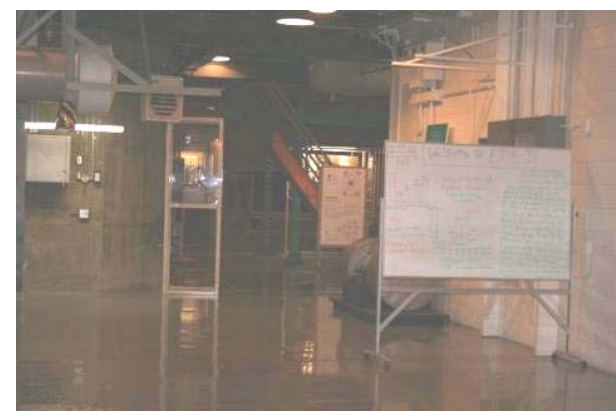

a

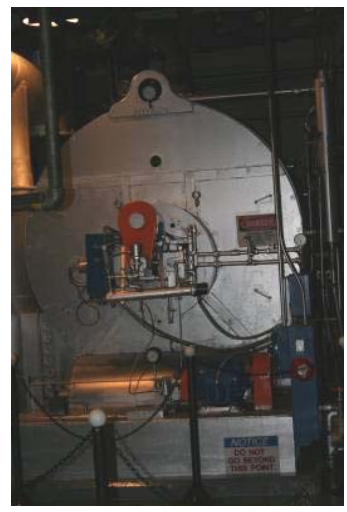

$\mathrm{b}$

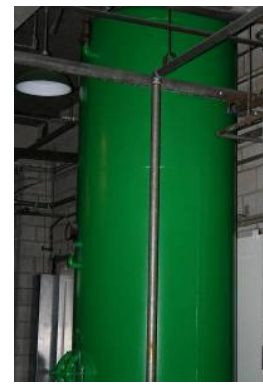

c

Figure 8. EBR I Reactor Building Ground Floor: lack of age related patina on a) floors, b) equipment, and c) newly painted equipment.

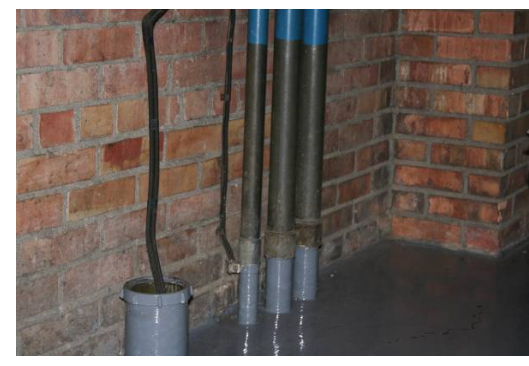

a

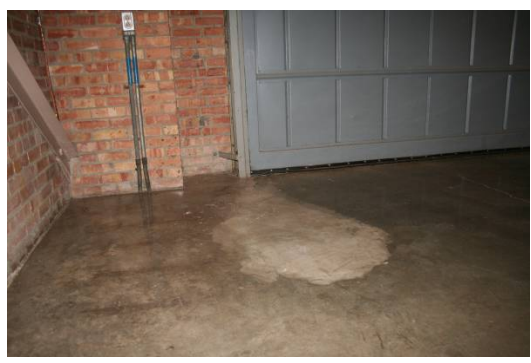

b

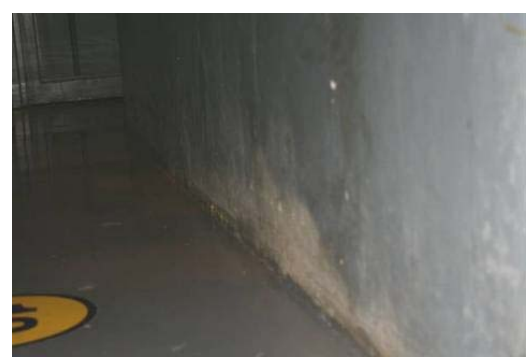

C

Figure 9. EBR I Reactor Building Ground Floor: stains on floors and walls in a) Service Room, b) near roll up door, and c) exterior wall of Hot Cell.

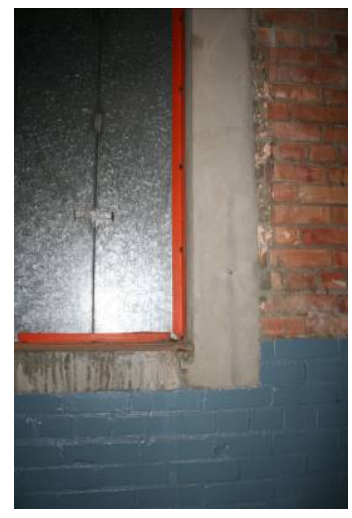

a

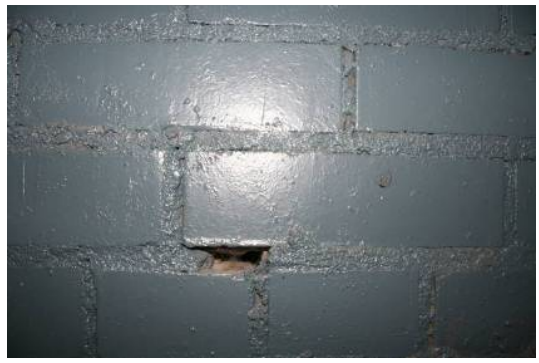

$\mathrm{b}$

Figure 10. EBR I Reactor Building Ground Floor: brick and mortar damage masked by a) patches and b) painting. 
Table 6. EBR I Reactor Building Ground Floor findings.

\begin{tabular}{|c|c|c|c|c|}
\hline Issue & $\begin{array}{c}\text { Probable } \\
\text { Cause } \\
\end{array}$ & $\begin{array}{c}\text { Testing and } \\
\text { Investigation }\end{array}$ & $\begin{array}{c}\text { Impact on the } \\
\text { Structure } \\
\end{array}$ & Mitigation and Repair \\
\hline $\begin{array}{l}\text { Shortage of } \\
\text { age-related } \\
\text { patina (Figure } \\
8 \mathrm{a}, 8 \mathrm{~b}, 8 \mathrm{c}) \\
\end{array}$ & $\begin{array}{l}\text { Over-zealous } \\
\text { maintenance }\end{array}$ & Visual Inspection & $\begin{array}{l}\text { Detracts from } \\
\text { historic } \\
\text { appearance and } \\
\text { feel }\end{array}$ & $\begin{array}{l}\text { Allow materials to reveal } \\
\text { their age without impacting } \\
\text { their fabric }\end{array}$ \\
\hline $\begin{array}{l}\text { Stains on } \\
\text { floor and } \\
\text { walls of } \\
\text { Service Room } \\
\text { (Figure 9a) }\end{array}$ & $\begin{array}{l}\text { Water } \\
\text { penetration on } \\
\text { windward side } \\
\text { of Reactor } \\
\text { Building }\end{array}$ & $\begin{array}{l}\text { Surveillance after } \\
\text { rain and snow melt }\end{array}$ & $\begin{array}{l}\text { Stains and } \\
\text { deterioration of } \\
\text { brick and concrete }\end{array}$ & $\begin{array}{l}\text { Some drainage problems } \\
\text { have been fixed; monitor to } \\
\text { see if moisture is present } \\
\text { after rains and snows. If } \\
\text { water is present, track on } \\
\text { exterior of building and } \\
\text { identify cause (ie., coping } \\
\text { gaps); replace concrete and } \\
\text { brick or repoint, as needed } \\
\text { under supervision of } \\
\text { qualified professionals. }\end{array}$ \\
\hline $\begin{array}{l}\text { Stains on } \\
\text { floor near } \\
\text { garage door } \\
\text { and wall near } \\
\text { Hot Cell } \\
\text { (Figure 9b, } \\
\text { 9c) }\end{array}$ & $\begin{array}{l}\text { Water seepage } \\
\text { on Westside of } \\
\text { Reactor } \\
\text { Building }\end{array}$ & $\begin{array}{l}\text { Surveillance after } \\
\text { rain and snow melt }\end{array}$ & $\begin{array}{l}\text { Stains and } \\
\text { deterioration of } \\
\text { brick and concrete }\end{array}$ & $\begin{array}{l}\text { Some drainage problems } \\
\text { have been fixed. Monitor } \\
\text { to see if moisture is present } \\
\text { after rains and snows. If } \\
\text { water is present, track on } \\
\text { exterior of building and } \\
\text { identify cause (ie., coping } \\
\text { gaps); replace concrete and } \\
\text { brick or repoint, as needed } \\
\text { under supervision of } \\
\text { qualified professionals. }\end{array}$ \\
\hline $\begin{array}{l}\text { Painted brick } \\
\text { and concrete } \\
\text { patches on } \\
\text { wall near Hot } \\
\text { Cell hide } \\
\text { brick and } \\
\text { mortar } \\
\text { deterioration } \\
\text { (Figure } 10 \mathrm{a}, \\
\text { 10b) }\end{array}$ & $\begin{array}{l}\text { Water } \\
\text { penetration into } \\
\text { Hot Cell area, } \\
\text { freeze/thaw }\end{array}$ & $\begin{array}{l}\text { Surveillance after } \\
\text { rain and snow melt }\end{array}$ & $\begin{array}{l}\text { Brick and mortar } \\
\text { deterioration }\end{array}$ & $\begin{array}{l}\text { Some drainage problems } \\
\text { have been fixed. Monitor } \\
\text { to see if moisture is present } \\
\text { after rains and snows. If } \\
\text { water is present, track on } \\
\text { exterior of building and } \\
\text { identify cause (ie., coping } \\
\text { gaps); replace concrete and } \\
\text { brick or repoint, as needed } \\
\text { under supervision of } \\
\text { qualified professionals. }\end{array}$ \\
\hline
\end{tabular}




\section{CONCLUSIONS AND RECOMMENDATIONS}

DOE has jurisdiction over the EBR I reactor building and, as a federal agency, is required by laws to preserve and protect this National Historic Landmark (36 CFR Part 65). In recognition of this important stewardship responsibility, DOE directed its contractor Cultural Resource Management Office staff to research its options and responsibilities and to prepare this Plan.

The EBR I area has been significantly altered by the removal of most of the structures that were extant in 1966 when EBR I was designated a Landmark; however, the EBR I reactor building and nearby guard house remain intact. Although the Landmark experienced deferred maintenance, it is in relatively good condition. The growing awareness by DOE and the contractor landlord of the importance of the Landmark area and the relationship between preservation and maintenance will greatly benefit its historic fabric and longevity. The following recommendations are made to further ensure EBR I's preservation.

The issues identified and recommended treatments presented in this Plan will be completed as prioritized and as funding allows using an incremental approach that takes into account the entire environment and whole building system. All treatments must be conducted by, or under the direct supervision of, persons who have extensive experience working with historic buildings and fabrics. The CRM Office staff shall assist the landlord in identifying qualified personnel. Qualified personnel shall assist in determining appropriate materials for the environment (i.e., brick and mortar composition). Recommendations at the present time include:

- $\quad$ Flat roofs, like those at EBR I are guaranteed to eventually leak. Ensure roof inspections include inspection of drain spouts with corrective actions implemented, as necessary.

- $\quad$ Cleaning must be conducted using the most gentle solutions and methods.

- $\quad$ Sandblasting of brick and sealant are forbidden.

- $\quad$ Remove reflective film on windows and investigate and install other ways to keep the second story conference room cool.

- Install an adequate external drainage system around the building to keep water away from the building to avoid absorption, deabsorption, and efflorescence.

- Implement an ongoing program to repoint or replace spalling brick and mortar.

- $\quad$ Remove displays that do not relate to the central nuclear theme. 
- The landlord shall record observations and work performed on EBR I in a log book and contact the appropriate supervisor and the CRM Office staff when unanticipated impacts occur.

- $\quad$ The cleaning staff will be trained to look for and report any issues to the landlord that they observe.

- Interested parties will form an EBR I Board, comprised of the DOE-ID Cultural Resources Coordinator, contractor CRM Office staff, the contractor landlord, and public affairs staff. The Board shall review all proposed activities at EBR I including but not limited to: maintenance, system and building upgrades, interior and exterior displays and exhibits, and document their decisions.

- Update the original National Register nomination form to include specific boundaries for the Historic Landmark.

- $\quad$ Rehabilitate the EBR I guardhouse and open it to public visitation in order to enhance visitors experience. 


\section{REFERENCES}

Arrowrock Group, 1997, "INEEL A Historical Context and Asessment, Inventory and Narrative," INEEL/EXT-97-01021, Idaho Falls: U.S. DOE, 1997.

Fielden, Bernard M., 2003, Conservation of Historic Buildings, $3^{\text {rd }}$ ed., Boston: Architectural Press.

Green, Dr. Mel, 2005, personal communication with the author, Goucher College HP627 course lectures, August 2005.

Harris, Samuel Y., 2001, Building Pathology: Deterioration, Diagnostics, and Intervention, pp. 438-441, New York: John Wiley and Sons, Inc.

Idaho National Engineering Laboratory, 1989, INEL News 1989, copy available at the INL Technical Library and the INL Cultural Resources Management Office, Idaho Falls, Idaho.

Miley, Don and Harlan Summers, personal communication with author, September 22, 2005.

Miller, Dr. Hugh, 2005, personal communication with the author, Goucher College HP626 course lectures, August 2005.

Smith, Hinchman, and Grylls, 1949, Survey Report: Fort Peck, MT-Pocatello, ID Sites, pp. 22-23, Washington D.C.: GPO.

Stacy, Susan M., 2000, Proving the Principle: The History of the Idaho National Engineering and Environmental Laboratory, 1949-1999, Washington, D.C.: GPO.

U.S. Atomic Energy Commission, 1969, Thumbnail Sketch 1969, copy available at the INL Technical Library and the INL Cultural Resources Management Office, Idaho Falls, Idaho.

U.S. Department of Energy-Idaho Operations, 2007, Idaho National Laboratory Cultural Resource Management Plan, DOE-ID-10997, Idaho Falls: U.S. DOE.

Weaver, Martin E., 1997, Conserving Buildings: A Manual Techniques and Materials, New York: John Wiley and Sons, Inc. 